University of Nebraska - Lincoln

DigitalCommons@University of Nebraska - Lincoln

USDA National Wildlife Research Center - Staff

Publications

U.S. Department of Agriculture: Animal and Plant Health Inspection Service

April 2000

\title{
Long-term spatial stability of coyote (Canis latrans) home ranges in southeastern Colorado
}

Ann M. Kitchen

Utah State University, Logan, UT

Eric M. Gese

Utah State University, eric.gese@usu.edu

Edward R. Schauster

Utah State University, Logan, UT

Follow this and additional works at: https://digitalcommons.unl.edu/icwdm_usdanwrc

Part of the Environmental Sciences Commons

Kitchen, Ann M.; Gese, Eric M.; and Schauster, Edward R., "Long-term spatial stability of coyote (Canis latrans) home ranges in southeastern Colorado" (2000). USDA National Wildlife Research Center - Staff Publications. 636.

https://digitalcommons.unl.edu/icwdm_usdanwrc/636

This Article is brought to you for free and open access by the U.S. Department of Agriculture: Animal and Plant Health Inspection Service at DigitalCommons@University of Nebraska - Lincoln. It has been accepted for inclusion in USDA National Wildlife Research Center - Staff Publications by an authorized administrator of DigitalCommons@University of Nebraska - Lincoln. 


\title{
Long-term spatial stability of coyote (Canis latrans) home ranges in southeastern Colorado
}

\author{
Ann M. Kitchen, Eric M. Gese, and Edward R. Schauster
}

\begin{abstract}
Long-term stability of territorial boundaries has not been well documented in canids. To evaluate the prevalence of long-term spatial stability of coyote (Canis latrans) home ranges, we compared the overlap of territorial boundaries and the spatial distribution of telemetry locations of packs in southeastern Colorado. From August 1983 to July 1988 (period 1), 16 coyotes from six packs were radio-tracked. From April 1996 to August 1997 (period 2), 12 coyotes from six packs were captured and tracked in the same area. Mean percentage of overlap of pack ranges was $89.8 \pm 8.3 \%( \pm \mathrm{SD})$ for period 1 ranges over period 2 ranges and $55.8 \pm 14.4 \%$ for period 2 ranges over period 1 ranges. Mean percentage of overlap of the 30\% core area of the home ranges was $65.2 \pm 13.9 \%$ for those of period 1 over those of period 2 and $66.3 \pm 28.7 \%$ for those of period 2 over those of period 1. Despite substantial overlap of home-range and core-use areas, there were significant differences in the distribution of locations between periods in five of six home ranges. This suggests that, although packs are faithful to one site (i.e., boundaries remain similar over a period of years), their use of the site (i.e., distribution of locations within the range) may change temporally.
\end{abstract}

Résumé : La stabilité à long terme des limites territoriales chez les canidés est encore mal connue. Dans le but d'évaluer la stabilité spatiale à long terme des domaines chez le Coyote (Canis latrans), nous avons comparé le chevauchement des limites territoriales et la répartition spatiale des repérages télémétriques chez des meutes du sud-est du Colorado. D'août 1983 à juillet 1998 (période 1), 16 coyotes appartenant à six meutes on été repérés par radio. D'avril 1996 à août 1997 (période 2), 12 coyotes appartenant à six meutes ont été capturés et suivis dans la même zone. Le chevauchement moyen des meutes exprimé en pourcentage a été de $89,8 \pm 8,3 \%$ (écart type) dans le cas des domaines enregistrés durant la période 1 par rapport à ceux enregistrés durant la période 2 et de $55,8 \pm 14,4 \%$ dans le cas des domaines enregistrés durant la période 2 par rapport à ceux de la période 1 . Le chevauchement moyen de la portion centrale $(30 \%$ ) des domaines a été de $65,2 \pm 13,9 \%$ (période 1 sur période 2) et de 66,3 $\pm 28,7 \%$ (période 2 sur période 1). En dépit du chevauchement important des domaines et des zones centrales, il y avait des différences significatives de la répartition des sites de repérage entre les périodes dans cinq des six domaines. Ces résultats indiquent que malgré la fidélité des meutes à un endroit (i.e., similitude des limites durant plusieurs années), l'utilisation de l'endroit (i.e., répartition des sites de repérage dans le domaine) peut changer temporairement.

[Traduit par la Rédaction]

\section{Introduction}

Long-term spatial stability of home ranges in animals incorporates both individual site fidelity as well as the continued use of the site by members of the social group or population. Site fidelity among individuals has been documented in a wide variety of species, including birds (Greenwood and Harvey 1982; Lindberg and Sedinger 1998), mammals (Twiss et al. 1994; Law 1996), reptiles (Webb and Shine 1997), amphibians (Waldman et al. 1992), fish (Northcote 1997; Pellett et al. 1998), insects (Alcock 1996; Switzer 1997), and molluscs (Iwasaki 1995). The term site fidelity has been applied to various behaviors associated with repeti-

Received July 14, 1999. Accepted October 18, 1999.

A. Kitchen and E.R. Schauster. Department of Fisheries and Wildlife, Utah State University, Logan, UT 84322-5210, U.S.A.

E.M. Gese. ${ }^{1}$ National Wildlife Research Center, Department of Fisheries and Wildlife, Utah State University, Logan, UT 84322, U.S.A.

${ }^{1}$ Author to whom all correspondence should be addressed (e-mail: egese@cc.usu.edu). tive or continuous use of previously occupied space, for example, repetitive return to breeding (Kavanagh and Murray 1996), nesting (Pledger and Bullen 1998), or feeding (Irons 1998; Weinrich 1998) grounds or faithfulness to a territory (Peterson et al. 1998).

The adaptiveness of home-range stability varies with a number of environmental and individual characteristics. Continued use of a site by an individual appears to be positively related to the cost of changing territories, age, previous reproductive success, and the probability of mortality in the habitat (Gratto et al. 1985; Switzer 1993). The benefits of site familiarity gained from continued use of an area include knowledge of foraging areas, shelter, and breeding opportunities. Frequent movement of territories may leave an animal vulnerable to unknown predatory pressures or aggressive conspecifics. Conserving energy for lactation and reducing juvenile mortality by maintaining familiarity with resource distribution may explain site fidelity in female red kangaroos (Macropus rufus) in arid western Australia (Norbury et al. 1994). Site fidelity in the ruff (Philomachus pugnax) is thought to facilitate stable dominance relationships, which are important to all territorial males using lek sites (Widemo 1997). 
In certain circumstances, however, site fidelity may not be adaptive. Site fidelity is likely to be inversely related to heterogeneity in territory quality and the animal's lifespan (Switzer 1993). Warkentin and Hernandez (1996) noted that species of nearctic-neotropical migrant songbirds that exhibit high levels of site fidelity might be less adaptable to habitat degradation and loss. This has important conservation implications, owing to the vulnerability of these species to population declines with the increases in deforestation of tropical zones. Strong site fidelity and small population size have been implicated in low within-island genetic variability, which has likely led to inbreeding in the endangered Hawaiian monk seal (Monachus schauinslandi) in the northwestern Hawaiian islands (Kretzmann et al. 1997). The high degree of site fidelity found in the threatened broad-headed snake (Hoplocephalus bungaroides) in Australia (Webb and Shine 1997) also has conservation implications. To facilitate recovery of the species, researchers were interested in the feasibility of natural recolonization of "restored" habitats. However, strong site fidelity, coupled with low rates of dispersal of juvenile snakes, mitigates against successful recolonization of rehabilitated habitats.

An understanding of the extent of long-term spatial stability of site use exhibited by an animal is important in making appropriate management and control decisions. For example, the commonly held belief among landholders in Australia is that dingoes (Canis familiaris dingo) travel $20-40 \mathrm{~km}$ to kill sheep (Harden 1985). However, studies have documented limited movements and strong site fidelity in dingoes, indicating that sheep depredations are likely to be caused by animals living on or adjacent to farms (Harden 1985; Thomson et al. 1992). Site-faithful behavior is important to pup-removal or reduction management techniques used for coyotes (Canis latrans), in which long-term site fidelity of sterile or otherwise nonreproducing coyotes (which are less likely to depredate sheep as they lack pups to feed) near properties reduces the likelihood of reproducing animals becoming established in the area (Till and Knowlton 1983).

The level and extent of site-use stability in canids has not been well documented. Peterson and Page (1988) and Peterson et al. (1998) reported that wolf (Canis lupus) packs on Isle Royale occupied territories for several years and that new packs occupied similar territories of previous packs. In these cases, the researchers hypothesized that a single noncollared wolf from the previous pack may have founded the new pack. Similarity was also evident in the spatial organization of the entire population, with space-use patterns in the mid-1980s resembling those of the early 1960s '(Peterson and Page 1988), indicating that members of the wolves' social groups or population maintained ranges similar to those of previous territory holders. Fuller (1989) referred to the relatively stable, long-established territorial boundaries of wolves in north-central Minnesota. During a 10-year study, Thomson et al. (1992) found that dingoes in northwestern Australia exhibited strong site fidelity, rarely travelling far out of their territories. Studies of coyotes have indicated that some coyote packs remain in the same area for $\geq 1$ year
(Bowen 1982; Bekoff and Wells 1986). We compared coyote home range distribution between 1983 and 1988 with that documented between 1996 and 1997 on the Pinon Canyon Maneuver Site, southeastern Colorado, to evaluate the prevalence of long-term spatial stability of coyote home ranges in a lightly exploited population.

\section{Methods}

The study area was located on the $1040 \mathrm{~km}^{2}$ Pinon Canyon Maneuver Site (PCMS), Las Animas County, Colorado. The climate is semi-arid with a mean annual precipitation ranging between 26 and $38 \mathrm{~cm}$. Mean monthly temperatures range from $-1^{\circ} \mathrm{C}$ in January to $23^{\circ} \mathrm{C}$ in July. Elevations range from 1310 to $1740 \mathrm{~m}$. The site consists of river canyons, limestone breaks, and open plains. The two main vegetation types are short-grass prairie and pinyon pine (Pinus edulis) - juniper (Juniperus monosperma) communities (Shaw et al. 1989). The study area was used primarily for cattle ranching prior to 1982 , during which time predator populations (mostly coyotes and swift fox (Vulpes velox)) were subjected to trapping and hunting. In 1982, the U.S. Army acquired the PCMS for military activities that involved month-long mechanized training sessions 3-4 times a year. Coyote removal on PCMS was prohibited from 1983 to 1986. In 1987 and 1988, coyotes on the southwestern third of the site were controlled (Gese and Rongstad). ${ }^{2}$ Trapping prior to 1982 and removal in 1987 and 1988 may have caused some instability in coyote packs. Since 1988, there has been no intensive removal, although occasional shooting of coyotes by hunters has occurred. Trapping and hunting of coyotes continues on the ranches surrounding the study area.

Coyotes were radio-collared and tracked from August 1983 to July 1988 (period 1) and from April 1996 to August 1997 (period 2 ) on the PCMS. In period 1, coyotes were captured using steel leg-hold traps, aerial darting (Baer et al. 1978), aerial net-gunning from a helicopter (Barrett et al. 1982; Gese et al. 1987), manual capture after aerial pursuit (Gese et al. 1987), or manual capture from all-terrain vehicles (Gese and Andersen 1993). In period 2, coyotes were captured by aerial net-gunning from a helicopter (Barrett et al. 1982; Gese et al. 1987). Each coyote was ear-tagged, aged by tooth wear (Gier 1968), sexed, weighed, and radiocollared. Transmitter mass was $<5 \%$ of the body mass of the animal (Eberhardt et al. 1982). All radio collars included a mortality sensor that activated after $6 \mathrm{~h}$ of no motion. All coyotes were released at the site of capture.

Locations were obtained by triangulating $2-3$ bearings of an animal's position within $10 \mathrm{~min}$. Triangulation angles were maintained between $20^{\circ}$ and $160^{\circ}$ (Gese et al. 1988). Animal positions were determined using the software package Locate (Pacer Ltd., Truro, N.S.). Telemetry error was determined with reference transmitters to be $\pm 8^{\circ}$. We attempted to obtain equal numbers of locations in all time periods throughout the day, to reduce bias in home range size estimates (Gese et al. 1990). Point locations were taken at $\geq 8$-h intervals. Aerial telemetry (Mech 1983) was employed to locate missing animals. Coyotes were considered to be resident pack members if they were sharing the same territory (Gese et al. 1988).

Point locations were used to determine home-range size (Gese et al. 1990) and spatial distribution. A minimum of 100 locations per coyote pack was used in home-range estimation. Home-range size and spatial overlap were determined using Calhome home-range analysis program (Kie et al. 1996) and Arcview 3.0 (Environmental Systems Research Institute, Inc., Redlands, Calif.). Home-range

\footnotetext{
${ }^{2}$ E.M. Gese and O.J. Rongstad. 1989. Final report: the ecology of coyotes on the Pinon Canyon Maneuver Site, Colorado 1983-1988. Direc-
} torate of Environmental Compliance and Management (DECAM), Fort Carson, Colo., unpublished report. 
sizes were calculated using the $95 \%$ adaptive kernel algorithm and core areas were calculated using the $30 \%$ adaptive kernel algorithm (Worton 1989). Core areas were assessed in addition to home ranges, to evaluate the spatial stability of high-use areas within the home range. The distance (kilometres) between the centroids of pack home ranges between the two periods and between seasons was also calculated.

Multiple response permutation procedures (MRPPs; Mielke et al. 1976) were used to examine changes in distributions of coyote locations or space-use patterns between the two periods, to elucidate changes in the internal structure of the home range. MRPPs compare the observed intragroup (for example, pack or season locations) average distances between any two locations with the average distances that would have resulted from all possible combinations of intergroup locations under the null hypothesis. Thus, the MRPP test statistic, $\delta$, is a linear combination of average within-group distance measures for the $n$ groups. The test does not assume normal distribution or equal variances (Zimmerman et al. 1985). MRPPs were also used to compare the distributions of coyote locations between seasons within a period (i.e., the seasons within period 1 were analyzed separately from those within period 2 ), to compare short-term as well as long-term changes in spaceuse patterns. For the purposes of analyses, we defined seasons on the basis of energetic demands (owing to climatic changes and prey abundance) and behavioral characteristics (including breeding, gestation, pup-rearing, and dispersal) as follows: pup-rearing season (15 April - 14 August), dispersal season (15 August - 14 December), and breeding-gestation season (15 December - 14 April).

As prey abundance can influence space-use and home-range patterns, estimates of prey abundance were obtained by spotlighting for lagomorphs. Spotlighting was done from a vehicle travelling $10-15 \mathrm{~km} / \mathrm{h}$ along transects. Over $550 \mathrm{kms}$ of transects were spotlighted in each period. Cottontail rabbits (Sylvilagus audubonii) and black-tailed jackrabbits (Lepus californicus) were identified, and both species were combined for analysis. The number of lagomorphs spotted per kilometre in surveys during the two periods were compared using Student's $t$ tests.

\section{Results}

From August 1983 to July 1988, 16 coyotes (eight male, eight female) from six packs were located 988 times using radiotelemetry. The number of individuals from packs 1 through 6 in period 1 were three, three, three, two, two, and three, respectively. In 1996 and 1997, 12 coyotes (seven male, five female) were captured in the same area in which the coyotes of period 1 were captured. The number of individuals from packs 1 through 6 (pack number was designated by position of home range and corresponds between the two periods) in period 2 were three, two, two, two, one, and two, respectively. We collected 1923 locations of these coyotes from April 1996 to August 1997. Coyote-pack home ranges documented in period 1 overlapped those documented in period 2 (Fig. 1). The mean $( \pm \mathrm{SD})$ percentage of overlap was $89.8 \pm 8.3 \%$ for period 1 home ranges over period 2 home ranges and $55.8 \pm 14.4 \%$ for period 2 home ranges over period 1 home ranges. The mean percentage of overlap for the $30 \%$ core area of the home-ranges was $65.2 \pm 13.9 \%$ for those of period 1 over those of period 2 and $66.3 \pm 28.7 \%$ for those of period 2 over those of period 1 . The mean distance between the centroids of pack home ranges between periods was $0.86 \pm 0.22 \mathrm{~km}$ (mean $\pm \mathrm{SE}$ ); this was not significantly greater than the distance between centroids between seasonal home ranges within packs within periods $(0.67 \pm 0.11 \mathrm{~km})(t=0.49, \mathrm{df}=40, P=0.434)$.

Even though period 1 and period 2 coyote home ranges were found to have substantial overlap, there was some variation between periods in the sizes of the home ranges for some packs. Overall, home ranges in period 2 were significantly smaller than those of period $1(t=2.36, \mathrm{df}=10, P<$ 0.05 ), with home ranges decreasing by as much as $59.84 \%$ (Fig. 1). On average, the home-range size decreased by $39.8 \%$. Lagomorph counts in period 1 were found to be significantly smaller than those in period 2 (mean number of lagomorphs/kilometre $\pm \mathrm{SD}=0.36 \pm 0.06$ and $0.84 \pm 0.26$, respectively; $t=4.24$, $\mathrm{df}=75, P<0.001$ ).

MRPPs indicated a significant change in space-use patterns from period 1 to period 2 for five of the six packs (Table 1). MRPPs also demonstrated significant differences in the distribution of locations between seasons for all packs during period 1 and for four of the six packs during period 2 (Table 2).

\section{Discussion}

The existence of long-term spatial stability among coyote home ranges on the PCMS is indicated by the substantial overlapping of period 1 home ranges by period 2 home ranges. In addition, a comparison of the distance between the centroids of pack home ranges showed that the mean distance between the centroids of period 1 and period 2 home ranges was not significantly larger than the distance between the centroids of home ranges of packs between seasons in any one period. Thus, coyote packs on our study site maintained relatively stable territories for over 10 years.

Despite long-term spatial stability of coyote packs in an area, there are a number of factors that may influence shortterm changes in space use within that area. The changes in home-range sizes between periods likely reflect short-term changes due to prey availability and distribution, and may have no influence on the level of spatial stability exhibited. Territorial expansion and contraction due to changes in resource abundance or pack dynamics have been well documented in canids and other animals (Fuller and Keith 1980; Messier 1985; Peterson and Page 1988). Fuller (1989) noted that the relatively stable, long-established territorial boundaries of wolves in north-central Minnesota fluctuated little with short-term changes in pack size.

Changes in small-scale space use were also evident in our study, through analysis of the distribution of coyote-pack locations. A number of authors have noted that home ranges of animals are often unevenly used, with animals concentrating their activities in certain areas and using others infrequently (e.g., Macdonald et al. 1980; Voigt and Tinline 1980; Laundre and Keller 1981). This differential use of the home range can vary over time. Significant differences in the distribution of locations for the majority of the coyote packs both between periods and between seasons indicate that coyotes vary their utilization of space within the territory despite maintaining the same site and home-range boundaries over a number of years.

This shift in the distribution of range use may be influenced by changes in prey distribution and abundance, habitat 
Fig. 1. Overlapping home ranges of coyote packs in periods 1 and 2 on Pinon Canyon Maneuver Site, Colorado.
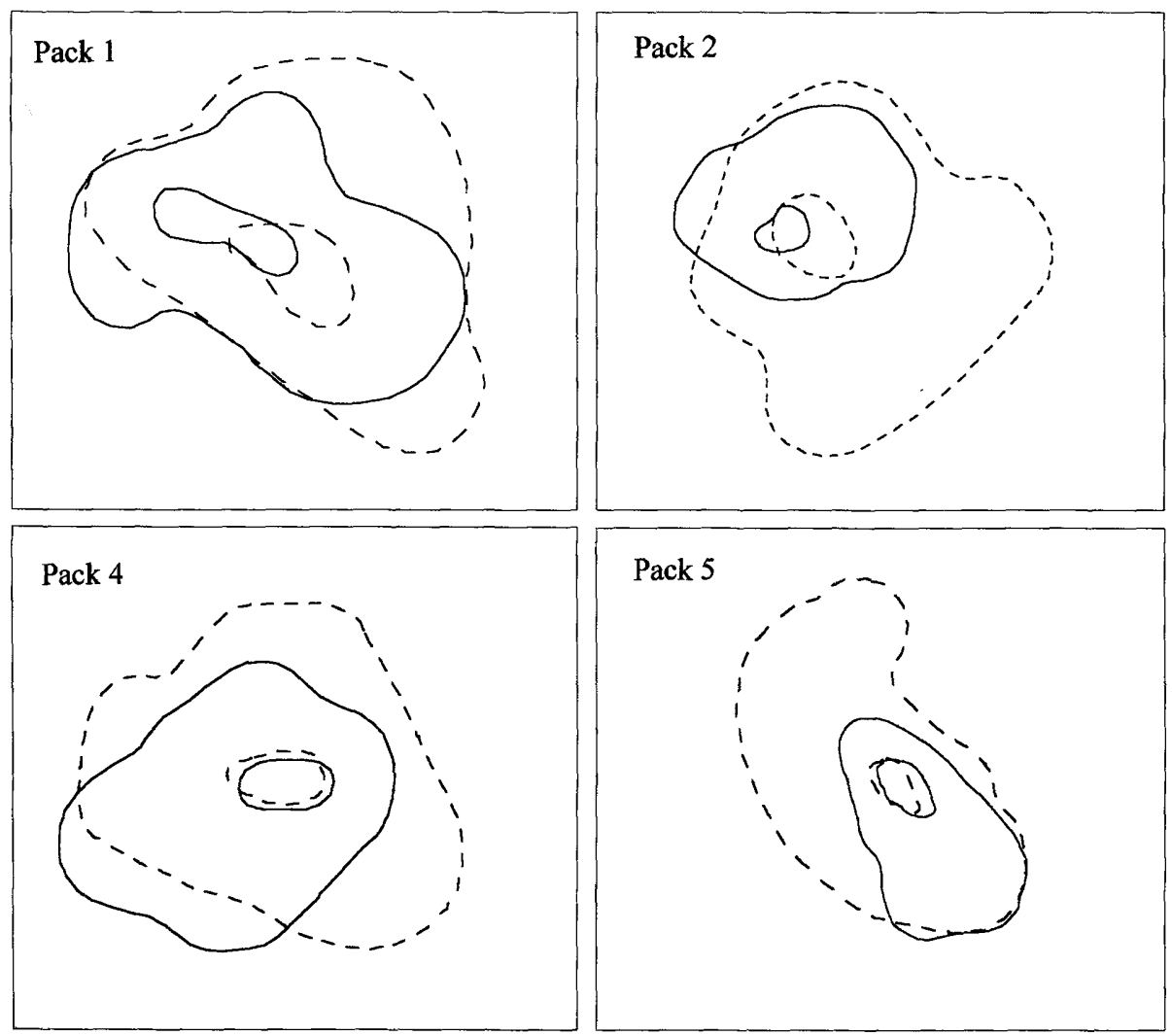

Pack 3
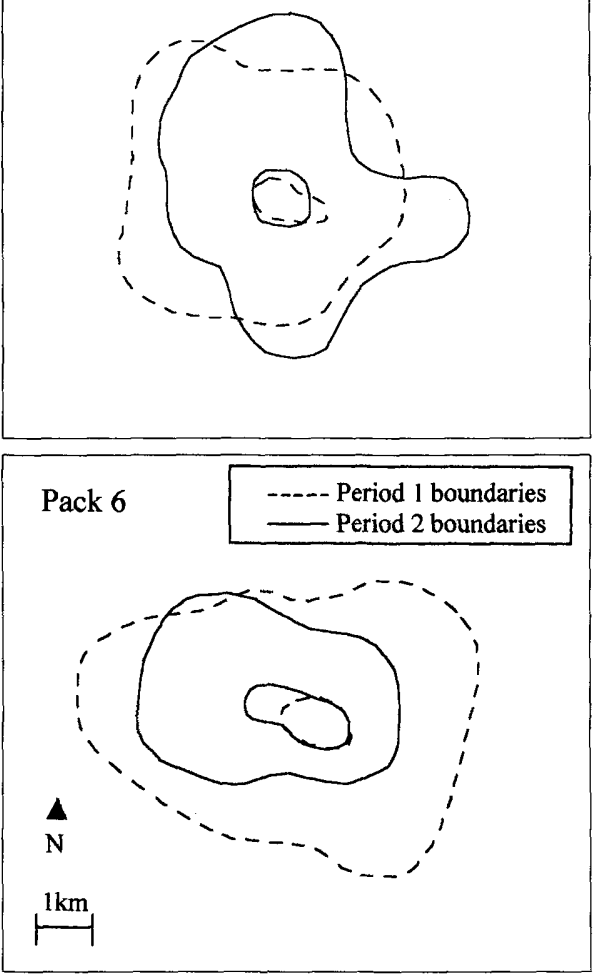

Table 1. Multiple response permutation procedures comparing the distribution of locations of overlapping packs in periods 1 and 2 on the Pinon Canyon Maneuver Site, Colorado.

\begin{tabular}{lrc}
\hline Pack No. & $\delta$ & $P$ \\
\hline 1 & 16.49 & $<0.001$ \\
2 & 100.22 & $<0.001$ \\
3 & 1.06 & 0.13 \\
4 & 13.33 & $<0.001$ \\
5 & 30.60 & $<0.001$ \\
6 & 20.60 & $<0.001$ \\
\hline
\end{tabular}

changes, and intra- and inter-pack dynamics. These variables have been shown to temporally influence space-use patterns in a number of animals. For example, Reid et al. (1994) noted that, in Alberta, space use by river otters (Lontra canadensis) was different in winter than in other seasons, owing to the need to find shelter with ready access to water (ice cover makes access to most water bodies problematic in winter). Temporal changes in the spatial distribution and availability of water also influenced the space-use patterns of raccoons (Procyon lotor) in Texas (Gehrt and Fritzell 1998). In some species, space use by males has been found to vary with changes in the distribution and density of females (e.g., Nelson 1995). Both lynx (Lynx canadensis) and coyotes were shown to shift their habitat-use patterns in response to changing prey (lagomorph) abundance among habitats (Murray et al. 1994). Bekoff and Wells (1986) doc-
Table 2. Multiple response permutation procedures comparing the distribution of locations between seasons within packs in periods 1 and 2 on the Pinon Canyon Maneuver Site, Colorado.

\begin{tabular}{llrr}
\hline Period & Pack No. & \multicolumn{1}{c}{$\delta$} & \multicolumn{1}{c}{$P$} \\
\hline 1 & 1 & 3.71 & $<0.01$ \\
& 2 & 2.64 & 0.02 \\
& 3 & 4.36 & $<0.01$ \\
& 4 & 2.72 & 0.02 \\
& 5 & 3.02 & 0.01 \\
& 6 & 2.07 & 0.04 \\
2 & 1 & 0.56 & 0.22 \\
& 2 & 12.09 & $<0.01$ \\
& 3 & 32.58 & $<0.01$ \\
& 4 & 19.85 & $<0.01$ \\
& 5 & 0.52 & 0.23 \\
& 6 & 11.42 & $<0.01$ \\
\hline
\end{tabular}

umented the differential use of home ranges with seasonal changes for coyotes, whereby the reproductive female spent an almost sixfold increase in time around the denning area during the pup-rearing season compared with other seasons.

Long-term spatial stability is likely an adaptive advantage for coyote packs, owing to increased familiarity with foraging areas and shelter in the territory. A pack exhibiting longterm spatial stability will also gain familiarity with packs holding neighboring territories and with interspecific competitors, which may reduce aggressive intra- and inter- 
specific interactions. A knowledge of resource distribution and the presence of potential competitors would be especially beneficial to coyote packs during pup-rearing seasons. Spatial stability in coyote packs may also facilitate stable dominance relationships, which are important for pack cohesiveness and territorial defense (Gese 1998).

The strong spatial stability exhibited by the coyote packs in this study may have been facilitated by the high density of coyotes in the area (Gese et al. 1989; Kitchen et al. 1999). An increase in site-use stability when the density of a population is close to habitat saturation has been documented in a number of animal species (e.g., Sterck 1998). The incidence of movement out of territorial areas by canids seems to increase with the ready availability of suitable resource-rich vacant areas (wolves, Fritts and Mech 1981; dingoes, Thomson et al. 1992). If higher-quality territories are available, remaining faithful to its present site may not be beneficial for an animal (Switzer 1993), although a number of additional variables may influence the adaptive advantage of site stability, including habitat stability (McNicholl 1975) and the variability of the quality of the habitat within the territory (Bench and Hasselquist 1991). Thus, the level of stability in long-term site use among coyote populations may vary with environmental, social, and individual factors.

Knowledge of coyote behavior, such as the spatial stability of home range, is becoming increasingly important in their management, owing to heightened efforts to restrict attempts to control them to localized areas. There is some evidence that coyotes will leave a territory, at least temporarily, to pursue prey (Shivik et al. 1996), or be unable to defend territories containing a large prey base from transients (Camenzind 1978). However, other studies have shown that when breeding coyotes hold territories containing sheep, they are the principal predators of the sheep (Althoff and Gipson 1981; Till and Knowlton 1983; Sacks et al. 1999). Thus, targeting coyotes that hold territories in the immediate vicinity of depredation will be more effective than targeting coyotes over a wider area (Sacks et al. 1999), especially in areas where these coyotes may otherwise hold their territories for a number of years. Alternatively, sterilizing site-faithful breeding coyotes that hold territories containing sheep may reduce depredation (which may occur primarily for pup provisioning) and lessen the chance of reproducing animals becoming established in the area (Till and Knowlton 1983).

The existence of long-term home range stability among coyote packs suggests the possibility of multigenerational site fidelity of packs, with territories being passed on to family members; this has been documented in wolves (Mech and Hertel 1983), jackals (Moehlman 1983), and red foxes (von Schantz 1981). Sharing and, later, inheriting a natal home range can provide an adaptive advantage for offspring in cases where there is little probability of obtaining a territory through dispersal, and may provide opportunities to indirectly increase fitness through assisting in sibling rearing (Myles 1988). Further research is needed to document the level of site inheritance within family groups among coyotes.

\section{Acknowledgements}

Many thanks to Becky Abel, Cass Bromley, Julian Colescott, Chris Gordon, Linda Gorman, Chad Hamlin, Racheal
Hare, Seija Karki, Mead Klavetter, Steve Langeland, Scott McLellan, Melissa Pangraze, Laurence Schafer, Laurie Schleub, Jen Stamp, Hilary Tall, Pat Terletzky, and Whitney Weber for field assistance. Dan Sharps, Bruce Roselund, Gary Belew, Chris Bandy, and Tom Warren provided technical and logistical support. Funding and logistical support was provided by the U.S. Army, Directorate of Environmental Compliance and Management (DECAM), Fort Carson, Colorado; the U.S. Fish and Wildlife Service, Colorado Fish and Wildlife Assistance Office, Golden, Colorado; the Northern Prairie Science Center, Jamestown, North Dakota; the USDA National Wildlife Research Center, Logan, Utah; the Utah Cooperative Fish and Wildlife Research Unit; and Utah State University Presidential and Berryman Fellowships to the senior author. Susan Durham helped with statistical support. Research protocols were approved by Institutional Animal Care and Use Committees at the National Wildlife Research Center and Utah State University.

\section{References}

Alcock, J. 1996. Site fidelity and homing ability of males of Dawson's burrowing bee (Amegilla dawsoni) (Apidae, Anthophorini). J. Kans. Entomol. Soc. 69: 182-190.

Althoff, D.P., and Gipson, P.S. 1981. Coyote family spatial relationships with reference to poultry losses. J. Wildl. Manage. 45: 641-649.

Baer, C., Severson, R.E., and Linhart, S.B. 1978. Live capture of coyotes from a helicopter with ketamine hydrochloride. J. Wildl. Manage. 42: 452-454.

Barrett, M.W., Nolan, J.W., and Roy, L.D. 1982. Evaluation of a hand-held net-gun to capture large animals. Wildl. Soc. Bull. 10: 108-114.

Bekoff, M., and Wells, M.C. 1986. Social ecology and behavior of coyotes. Adv. Study Behav. 16: 251-338.

Bench, S., and Hasselquist, D. 1991. Territory infidelity in the polygynous great reed warbler Acrocephalus arundinaceus: the effect of variation in territory attractiveness. J. Anim. Ecol. 60: 857-871.

Bowen, W.D. 1982. Home range and spatial organization of coyotes in Jasper National Park, Alberta. J. Wildl. Manage. 46: 201-216.

Camenzind, F.J. 1978. Behavioral ecology of coyotes on the National Elk Refuge, Jackson, Wyoming. In Coyotes: biology, behavior, and management. Edited by M. Bekoff. Academic press, New York. pp. 267-294.

Eberhardt, L.E., Hanson, W.C., Bengtson, J.L., Garrot, R.A., and Hanson, E.E. 1982. Arctic fox home-range characteristics in an oil-development area. J. Wildl. Manage. 46: 183-190.

Fritts, S.H., and Mech, L.D. 1981. Dynamics, movements, and feeding ecology of a newly protected wolf population in northwestern Minnesota. Wildl. Monogr. No. 80. pp. 1-79.

Fuller, T.K. 1989. Population dynamics of wolves in north-central Minnesota. Wildl. Monogr. No. 105. pp. 1-41.

Fuller, T.K., and Keith, L.B. 1980. Wolf population dynamics and prey relationships in northeastern Alberta. J. Wildl. Manage. 44: 583-602.

Gehrt, S.D., and Fritzell, E.K. 1998. Resource distribution, female home range dispersion and male spatial interactions: group structure in a solitary carnivore. Anim. Behav. 55: 1211-1227.

Gese, E.M. 1998. Response of neighboring coyotes (Canis latrans) to social disruption in an adjacent pack. Can. J. Zool. 76: 1960-1963. 
Gese, E.M., and Andersen, D.E. 1993. Success and cost of capturing coyotes, Canis latrans, from all-terrain vehicles. Can. FieldNat. 107: 112-114.

Gese, E.M., Rongstad, O.J., and Mytton, W.R. 1987. Manual and net-gun capture of coyotes from helicopters. Wildl. Soc. Bull. 15: $444-445$.

Gese, E.M., Rongstad, O.J., and Mytton, W.R. 1988. Home-range and habitat use of coyotes in southeastern Colorado. J. Wildl. Manage. 52: 640-646.

Gese, E.M., Rongstad, O.J., and Mytton, W.R. 1989. Population dynamics of coyotes in southeastern Colorado. J. Wildl. Manage. 53: 174-181.

Gese, E.M., Andersen, D.E., and Rongstad, O.J. 1990. Determining home-range size of resident coyotes from point and sequential locations. J. Wildl. Manage. 54: 501-506.

Gier, H.T. 1968. Coyotes in Kansas. Kansas State College Agricultural Experiment Station, Manhattan, Bull. No. 393.

Gratto, C.L., Morrison, R.I., and Cooke, F. 1985. Philopatry, site tenacity, and mate fidelity in the semipalmated sandpiper. Auk, 102: 16-24.

Greenwood, P.J., and Harvey, P.H. 1982. The natal and breeding dispersal of birds. Annu. Rev. Ecol. Syst. 13: 1-21.

Harden, R.H. 1985. The ecology of the dingo in north-eastern New South Wales I. Movements and home range. Aust. Wildl. Res. 12: $25-37$.

Irons, D.B. 1998. Foraging area fidelity of individual seabirds in relation to tidal cycles and flock feeding. Ecology, 79: 647-655.

Iwasaki, K. 1995. Dominance order and resting site fidelity in the intertidal pulmonate limpet Siponaria sirius (Pilsbry). Ecol. Res. 10: $105-115$.

Kavanagh, R.P., and Murray, M. 1996. Home range, habitat and behavior of the Masked Owls Tyto novaehollandiae near Newcastle, New South Wales. Emu, 96: 250-257.

Kie, J.G., Baldwin, J.A., and Evans, C.J. 1996. Calhome: a program for estimating animal home ranges. Wildl. Soc. Bull. 24: 342-344.

Kitchen, A.M., Gese, E.M., and Schauster, E.R. 1999. Resource partitioning between swift foxes and coyotes: space, time, and diet. Can J. Zool. 77: 1645-1656.

Kretzmann, M.B., Gilmartin, W.G., Meyer, A., Zegers, G.P., Fain, S.R., Taylor, B.F., and Costa, D.P. 1997. Low genetic variability in the Hawaiian monk seal. Conserv. Biol. 11: 482-490.

Laundre, J.W., and Keller, B.L. 1981. Home-range use by coyotes in Idaho. Anim. Behav. 29: 449-461.

Law, B.S. 1996. Residency and site fidelity of marked populations of the common blossom bat Syconycteris australis in relation to the availability of Banksia inflorescences in New South Wales, Australia. Oikos, 77: 447-458.

Lindberg, M.S., and Sedinger, J.S. 1998. Ecological significance of brood-site fidelity in Black Brant: spatial, annual and age-related variation. Auk, 115: 436-446.

Macdonald, D.W., Ball, F.G., and Hough, N.G. 1980. The evaluation of home range size and configuration using radio tracking data. In A handbook on biotelemetry and radio tracking. Edited by C.J. Amlaner and D.W. Macdonald. Pergamon Press, Oxford. pp. 405-424.

McNicholl, M.K. 1975. Larid site tenacity and group adherence in relation to habitat. Auk, 92: 98-104.

Mech, L.D. 1983. Handbook of animal radiotracking. University of Minnesota Press, Minneapolis.

Mech, L.D., and Hertel, H.H. 1983. An eight-year demography of a Minnesota wolf pack. Acta Zool. Fenn. 174: 249-250.

Messier, F. 1985. Social organization, spatial distribution, and pop- ulation density of wolves in relation to moose density. Can. J. Zool. 63: 1068-1077.

Mielke, P.W., Berry, K.J., and Johnson, E.S. 1976. Multiresponse permutation procedures for a priori classifications. Commun. Statist. Theor. Meth. 11: 1427-1437.

Moehlman, P.D. 1983. Socioecology of silverbacked and golden jackals, Canis mesolmelas and C. Anreus. In Recent advances in the study of mammalian behavior. Edited by J.F. Eisenberg and D.G. Kleiman. American Society of Mammalogists, Shippensburg, Pa. pp. 423-453.

Murray, D.L., Boutin, S., and O'Donoghue, M. 1994. Winter habitat selection by lynx and coyotes in relation to snowshoe hare abundance. Can. J. Zool. 72: 1444-1451.

Myles, T.G. 1988. Social evolution from termites to man. In The ecology of social behavior. Edited by C.N. Slobodchikoff. Academic Press, San Diego. pp. 379-423.

Nelson, J. 1995. Determinants of male spacing behavior in microtines: an experimental manipulation of female spatial distribution and density. Behav. Ecol. Sociobiol. 37: 217-223.

Norbury, G.L., Norbury, D.C., and Oliver, A.J. 1994. Facultative behavior in unpredictable environments: mobility of red kangaroos in arid Western Australia. J. Anim. Ecol. 63: 410-418.

Northcote, T.G. 1997. Potamodromy in Salmonidae: living and moving in the fast lane. N. Am. J. Fish. Manage. 17: 10291045.

Pellett, T.D., Van Dyck, G.J., and Adams, J.V. 1998. Seasonal migration and homing of channel catfish in the lower Wisconsin River, Wisconsin. N. Am. J. Fish. Manage. 18: 85-95.

Peterson, R.O., and Page, R.E. 1988. The rise and fall of the Isle Royale wolves, 1975-1986. J. Mammal. 69: 89-99.

Peterson, R.O., Thomas, N.J., Thurber, J.M., Vucetich, J.A., and Waite, T.A. 1998. Population limitation and the wolves of Isle Royale. J. Mammal. 79: 828-841.

Pledger, S., and Bullen, L. 1998. Tests for mate and nest fidelity in birds with application to little blue penguins (Eudyptula minor). Biometrics, 54: 61-66.

Reid, D.G., Code, T.E., Reid, A.C.H., and Herrero, S.M. 1994. Spacing, movements, and habitat selection of the river otter in boreal Alberta. Can. J. Zool. 72: 1314-1324.

Sacks, B.N., Jaeger, M.M., Neale, J.C., and McCullough, D.R. 1999. Territoriality and breeding status of coyotes relative to sheep predation. J. Wildl. Manage. 63: 593-605.

Shaw, R.B., Anderson, S.L., Schulz, K.A., and Diersing, V.E. 1989. Plant communities, ecological checklist, and species list for the U.S. Army Pinon Canyon Maneuver Site, Colorado. No. 37, Colorado State University, Sci. Ser. No. 37.

Shivik, J.A., Jaeger, M.M., and Barrett, R.H. 1996. Coyote movements in relation to the spatial distribution of sheep. J. Wildl. Manage. 60: 422-430.

Sterck, E. 1998. Female dispersal, social organization, and infanticide in langurs: are they linked to human disturbance? Am. J. Primatol. 44: 235-254.

Switzer, P.V. 1993. Site fidelity in predictable and unpredictable habitats. Evol. Ecol. 7: 533-555.

Switzer, P.V. 1997. Factors affecting site fidelity in a territorial animal, Perithemis tenera. Anim. Behav. 53: 865-877.

Thomson, P.C., Rose, K., and Kok, N.E. 1992. The behavioral ecology of dingoes in north-western Australia: VI. Temporary extraterritorial movements and dispersal. Wildl. Res. 19: 585-595.

Till, J.A., and Knowlton, F.F. 1983. Efficacy of denning in alleviating coyote depredations upon domestic sheep. J. Wildl. Manage. 47: 1018-1025.

Twiss, S.D., Pomeroy, P.P., and Anderson, S.S. 1994. Dispersion 
and site fidelity of breeding male grey seals (Halichoerus grypus) on North Rona, Scotland. J. Zool. (Lond.), 233: 683-693.

Voigt, D.R., and Tinline, R.R. 1980. Strategies for analyzing radio tracking data. In A handbook on biotelemetry and radio tracking. Edited by C.J. Amlaner and D.W. Macdonald. Pergamon Press, Oxford. pp. 387-405.

von Schantz, T. 1981. Female cooperation, male competition, and dispersal in the red fox, Vulpes vulpes. Oikos, 37: 63-68.

Waldman, B., Rice, J.E., and Honeycutt, R.L. 1992. Kin recognition and incest avoidance in toads. Am. Zool. 32: 18-30.

Warkentin, I.G., and Hernandez, D. 1996. The conservation implications of site fidelity: a case study involving nearctic-neotropical migrant songbirds wintering in a Costa Rican mangrove. Biol. Conserv. 77: 143-150.
Webb, J.K., and Shine, R. 1997. A field study of spatial ecology and movements of a threatened snake species, Hoplocephalus bungaroides. Biol. Conserv. 82: 203-217.

Weinrich, M. 1998. Early experience in habitat choice by humpback whales (Megaptera novaeangliae). J. Mammal. 79: 163-170.

Widemo, F. 1997. The social implications of traditional use of lek sites in the ruff Philomachus pugnax. Behav. Ecol. 8: 211-217.

Worton, B.J. 1989. Kernal methods for estimating the utilization distribution in home-range studies. Ecology, 70: 164-168.

Zimmerman, G.M., Goetz, H., and Mielke, P.W. 1985. Use of an improved statistical method for group comparisons to study effects of prairie fire. Ecology, 66: 606-611. 